(C) A.A. Novik, M.V. Domosiletskaya

\title{
THE FIG TREE IN ALIMENTARY CULTURE, FOLK MEDICINE AND TRADITIONS AMONG THE PEOPLES OF THE WESTERN BALKANS
}

Keywords: Western Balkans, fig tree, beliefs, magic, food, folk medicine, tradition, bio resources

\begin{abstract}
The article analyzes the role of the fig tree in various spheres of culture of the Albanians, Croats, Greeks, and other peoples of the Balkan Peninsula, as well as the use of its fruit as food and raw material for the production of alcoholic beverages and medicine. Until the 19th century, the pollination of the plant remained a mystery (not even Carl Linnaeus, the "father of botany" and the creator of the modern classification of wildlife species, was able to solve the complex puzzle of nature), which led to the emergence and proliferation of numerous mythologemes, still recorded to date, that are consistently associated with the fig tree. Currently, notions about the magical properties of the plant and its fruit are being transformed under the influence of the global passion for environmentally friendly bio products. The discussion specifically focuses on the mechanism through which such "new meanings" enter the public discourse.
\end{abstract}

This article is a translation of: А.А. Новик, М.В. Домосилецкая. Инжир в алиментарной культуре, народной медицине и традициях у народов Западных Балкан // Etnograficheskoe Obozrenie. 2021. No 5. P. 33-52. DOI: 10.31857/S086954150017413-4

\section{From the mysterious to the magical and the sacred}

Fig tree cultivation ${ }^{1}$ spread rather early in the Mediterranean, including the Ionian and Adriatic coasts. The birthplace of the plant is the Arabian Peninsula, from there it penetrated the Middle East, Asia Minor, the Balkan Peninsula, etc. (Sulaj 2013: 94; Common fig s.a.). The fig tree was appropriated by the Hellenes in the 9th century BC, and with the expansion of Greek colonization to the West and East, the plant first took root in the city-states, and then spread out to neighboring regions.

The fig tree is mentioned in biblical texts (Genesis. Ch. 3, 7). It has also become deeply ingrained in the folklore of various nations (Nopcsa 1913a: 66; Frazer 1990; Tirta 2004: 283). Slavic tribes that settled in the Balkan Peninsula in 5-7 centuries AD, found that the locals are well aware of this plant. Subsequently, the cultivationof the fig tree in the Western Balkan region has never been interrupted. The range of the tree/ semi-shrub varieties bred over many centuries of human economic activity allows the plant to survive in the most difficult conditions: figs grow in mountainous areas, on barren lands, tolerates frosts well up to $15-20^{\circ} \mathrm{C}$ below zero. The fruits of the fig tree

Alexander Novik | http://orcid.org/0000-0002-1123-1109| njual@mail.ru | Peter the Great Museum of Anthropology and Ethnography (Kunstkamera), Russian Academy of Sciences (3 University Emb., St. Petersburg, 199034, Russia)

Marina Domosiletskaya | https://orcid.org/0000-0002-5599-7878 | marinaling@mail.ru| Institute for Linguistic Studies, Russian Academy of Sciences (9 Tuchkov pereulok, St. Petersburg, 199053, Russia)

Etnograficheskoe Obozrenie. 2021. № 6. P. 224-241. https://doi.org/10.31857/S086954150017606-6 (C) Russian Academy of Science | (C) Institute of Ethnology and Anthropology, RAS ISSN 0869-5415 | http://journal.iea.ras.ru 
have traditionally been used fresh or processed; they have always been an important component of the Balkan cuisine peculiar of the peoples living in the Peninsula. However, until the 19th century, the plant remained a mystery to people who devoted their lives to cultivating it.

In the reproduction system (pollination and fruiting) of figs, a large role has always been played by the wild fig tree (caprifica) ${ }^{2}$. The fig tree develops three types of flowers: male (staminate), female short-styled (gall) and female long-styled. It is the latter that bear fruit. The inflorescences which form male and gall flowers are called syconia, they are small and hard, and pollen ripens in them. The gall flowers serve as incubators for the development of the blastophagous wasp (Blastophaga psenes), which then pollinates the fertile inflorescences. Aristotle was the first to suggest that there is some kind of connection between blastophages and ripening figs. However, for a long time the mystery of fig fertilization remained unsolved; even K. Linnaeus (1707-1778) failed to solve $i^{3}$. Biologists discovered the intricacies of the relationship between blastophages and figs only in the 19th century (Neer van der 2007: 56). In a wild fig tree, called caprifica (Latin caper "goat" and fīcus "fig tree, fig fruit") ${ }^{4}$, both syconia and fertile inflorescences are on the same tree, while in most cultivated species the former are formed on the trees of one kind, and the latter on others called figs. Nowadays, one male is usually planted for every 20 female trees (GRE s.a.). Mankind gradually came to the understanding that such a ratio is particularly necessary. The ancient Greeks already knew that many cultivars of fig trees do not produce fruit by themselves. Columella (1st century AD), an ancient Roman writer who covered the topic of agriculture in his writings, talked about the custom of hanging the branches of a wild fig tree on cultivated fig trees. It was believed that this practice would prevent unripe fruits from falling and contribute to their fast ripening (tempus est ficulneis arboribus caprifīcum suspendere - "time to hang a wild fig tree to fig trees"; Col. R. R. 11. 2. 56). The verb caprifico "to accelerate the ripening of figs" was noted in Pliny's texts (1st century AD) (André 1956: 70).

Currently mainly fig trees, giving parthenocarpic fruits are cultivated. Greek

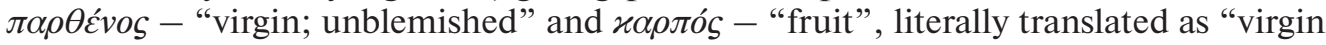
fruit"; a particular instance of parthenogenesis, virgin fertilization without pollination in plants usually with the formation of seedless fruits (LOP 1980: 271). However, the old way of fig trees caprification is still remembered in the Balkans (Lafe 2008: 676) (see in this connection the Albanian figurative expression that still exists today: I martoi fiqtë, lit. "married fig trees" (Gjevori 1979: 69), referring to how the gardener acts when he hangs wild branches to a cultivated fig tree).

The fig tree plays a significant role in the intellectual culture of the Western Balkan nations. The plant reproductive system, which remained a mystery for several millennia, led to the emergence of strongly held views about the spirits of nature, secrets and magical properties of figs (Tolstoy 1995-2012; Tirta 2004: 57-61; Tolstaya 2019). The miraculous powers of the fig tree are manifested primarily in the system of the Balkan protective rituals. For example, the Serbs believed that in bad weather, especially during a thunderstorm, one should light up a fig tree branch consecrated on White Saturday (the first Saturday after Trinity Sunday) and make the sign of the cross over an approaching cloud with it (Chaykanovich 1985: 220).

The image of the fig tree in Greek folklore is somewhat contradictory: it is venerated as a plant with a reproducing power, and at the same time is considered a "cursed tree" (it is believed that the devil lives in the fig tree, so you cannot sleep under its shade). The former idea echoes the biblical story about the fall of Adam and Eve, who covered their nakedness with the fig tree leaves (that is, the fig tree is "the tree of disobedience"). The latter is a reminiscence of the Gospel parable (Matthew. Ch. 21. Verses 18-22), which has a deeper symbolic meaning: on one occasion Christ was hungry and asked 
for fruit from the fig tree, but it refused, so he cursed it. And one of the legends recorded among the Greeks tells of a cursed fig tree, from under the roots of which a lamb emerges. If a person finds himself in the shadow of this tree, then a needle seems to be thrust into his leg, the lamb turns into a nereid and kidnaps the unfortunate traveler. Sometimes a person can return, but already being insane or sick. At the same time, there exist a lot of modern Greek folk legends and stories telling that icons were found on a fig tree or that it was planted by a revered saint (Sidneva 2008: 58-59, 86).

Albanians, Greeks, Montenegrins, Serbs, Croats and other peoples still have ideas about sacred trees and sacred groves. Here is just one example to illustrate this. In the late 2000s, an American-Turkish company, which won a tender within the framework of the European Union project for the development of transport networks, was building a highway connecting Albania with Kosovo (Alb. Rruga e Kombit - "Road of the Nation"). Campaigns by local residents protesting against cutting down of sacred groves in certain areas led to the fact that the original project was altered: the modern highway ended up with several sharp turns, guaranteeing the preservation of sacred places (AMAE 2009). According to the materials we collected during our expeditionary work in the Balkans in 1990-2021, people still believe that a separate tree or a group of trees/ shrubs can be protected by the spirit of the place/area/land, or the spirit can dwell in the plant itself, protecting it from any encroachments by humans or animals. The basis of such views can be found in very old pantheistic ideas concerning the structure of the world (Nopcsa 1913b; Tirta 2004: 57-61). These beliefs underwent various stages in the course of the mythological and religious development of the Balkan peoples and were able to withstand the battle with the polytheistic and monotheistic beliefs spreading in the region: the pantheon of Greek and Roman gods and heroes, Christian Orthodoxy and Catholicism, Islam in its various forms (in the west of the Balkan Peninsula the most widespread were and still remain the teachings of the Sunnis and Bektashi) (Novik, Rezvan 2019). Remnants of such beliefs persisted even in the era of militant atheism (1944-1991), they are still present today under the conditions of the spread of digital technologies and the total domination of mass culture, which almost completely subjugated the global information space.

A single growing tree and a group of fig trees / dwarf shrubs in some places are also perceived as sacred if certain beliefs or legends are associated with them. A striking example of this is the Maligrad Island on Great Prespa Lake (borderlands of Albania and North Macedonia). The island, which is officially part of the Albanian territory, is famous not only for its perfectly preserved church with frescoes of the 14th century, depicting (besides the saints) the churchwarden Caesar Novak in clothes characteristic of that era (for more details see: Gjergji 1988: 17-20), but also for the thickets of fig trees covering almost all of the vacant space (see Pic. 1). Among the local population, Macedonians and Albanians, regardless of the religion professed, there is a strong conviction that this is a holy place and the fig trees should not be gathered here "so as not to disturb the peace", otherwise "Zana ${ }^{5}$ will punish you" (FMA 2008).

It is clear that such a practice and belief can be explained in a much more pragmatic way: figs from wild trees are much less tasty and edible than from their "cultivated relatives". However, local residents are willing to tell various stories about how those who dared to disturb the peace of the places where once was the capital of the Bulgarian king Samuil ${ }^{6}$ were punished, and now everything is overgrown with fig trees (our informants know about the king himself, of course, from the media or from school textbooks, however, they are ready to assert that the memories about a harsh ruler are steadily passed from generation to generation in their native places) (AMAE 2008). The use of the fig tree in the calendar holiday rituals of the Balkan peoples is very significant - although due to its poor quality its wood is practically not in demand. Endowing the tree with ritual power (in no small measure because of the mystery of fruiting, which has been preserved 
for almost three millennia of its cultivation in the macroregion) contributes to the steady entry of figs into ritual practices. Thus, in the west of the Balkans, various ritual activities associated with the trees are still recorded during the change of the calendar year (in the system of modern chronology) (Plotnikova 2004: 95-102). Among the Albanians (in Albania, Kosovo, in the western regions of North Macedonia and in the south of Montenegro), these actions are associated with buzmi (Alb. búz/ëm, -mi) - this is the name of a ceremonial tree (or several trees or logs), which is brought home and put in the open hearth fire on the night when the sun turns towards summer. Therefore, historically, the custom has to do with festive rituals and is closely related to the sun cult (Tirta 2007). The tradition connects ritual practices using buzmi with Christmas night (Nata e Kërshëndellave) (December 24), carols (kolendra), New Year's night (nata e Vitit të Ri) (December 31) (Novik 2014: 72-73). The time of burning the buzmi depends on the province (Alb. krahin/ë, $-a-$ historical and ethnographic area) or the region. In these actions, one can see the desire to increase the yield of arable land, orchards, vineyards, offspring of livestock and poultry, as well as replenishment in the family through magical practices (Tirta 2006: 443-449).

In 1996, during an expedition to Dukagjin, one of the authors of this study recorded the beliefs of local residents (the main materials were recorded in lagja ${ }^{7}$ Abat) that buzmi is a sacrifice that is made to appease the forces of nature (FMA 1996; Novik 2002: 145-165). The Albanian ethnographer M. Tirta, a native of Orosh in Mirdita, neighboring with the Dukagjin province, writes that "... we are dealing with a deity of the plant world; this demon or deity dies on a certain day only to be reborn again" (Tirta 2004: 282). In a number of regions of Southern and Central Albania, where the cultivation of the fig tree is traditionally an important agricultural activity, a log or branch of this tree is brought in during the preparation for the holiday. They are set on fire in the hearth with the hope of a future good harvest of fruit crops and grapes. This tradition differs from the practices of the South Slavs, who mainly used and continue to use oak wood in such rituals (Plotnikova 2004: 95-102). Calendar signs are also associated with reproducing magic "for the harvest". Serbs cannot eat figs until the Transfiguration holiday (August 6/19) - on this day they "receive communion" (Chaykanovich 1985: 220).

The magical is often correlated with the religious. For the Muslims of the region, fig fruits are strongly associated with the festive table. For example, dried figs are an indispensable component of the feasts held in Ramadan and Kurban Bayram, it is believed to be the "right" and desirable food during iftar - breaking the religious fast in the holy month of Ramadan (Sobolev, Novik 2013). In folk Islam, the fig tree and its fruits are perceived as a gift sent to people by Allah - this is evidenced by our materials recorded from the Turks of Ohrid, Skopje (North Macedonia), the Bosniacs of Mostar (Bosnia and Herzegovina), the Turks and Albanians of Prizren (Kosovo) (FMA 2011, 2018, 2019; AMAE 2019). So, today we can state the generally sustainable preservation of ideas about a fig tree as an important, useful, as well as a sacred plant in the culture, beliefs and ritual practices of the Balkan peoples, regardless of their confessional affiliation and dialects they speak.

\section{Fig tree in the economy, alimentary sphere, in the ethnic and religious self-identification of the Balkan nations}

The fig tree would not have acquired such importance in spiritual life if its fruits were not so much in demand in the alimentary sphere of the inhabitants of the region.

As a food product, fig fruits are used everywhere in the western Balkans (as well as in Southeast Europe in general). The degree of their dietary intake depends on the geographic zone: if in some area the plant grows in sufficient quantity, then there will be a lot of fig products on the table of local residents, but if it is cultivated in a limited 


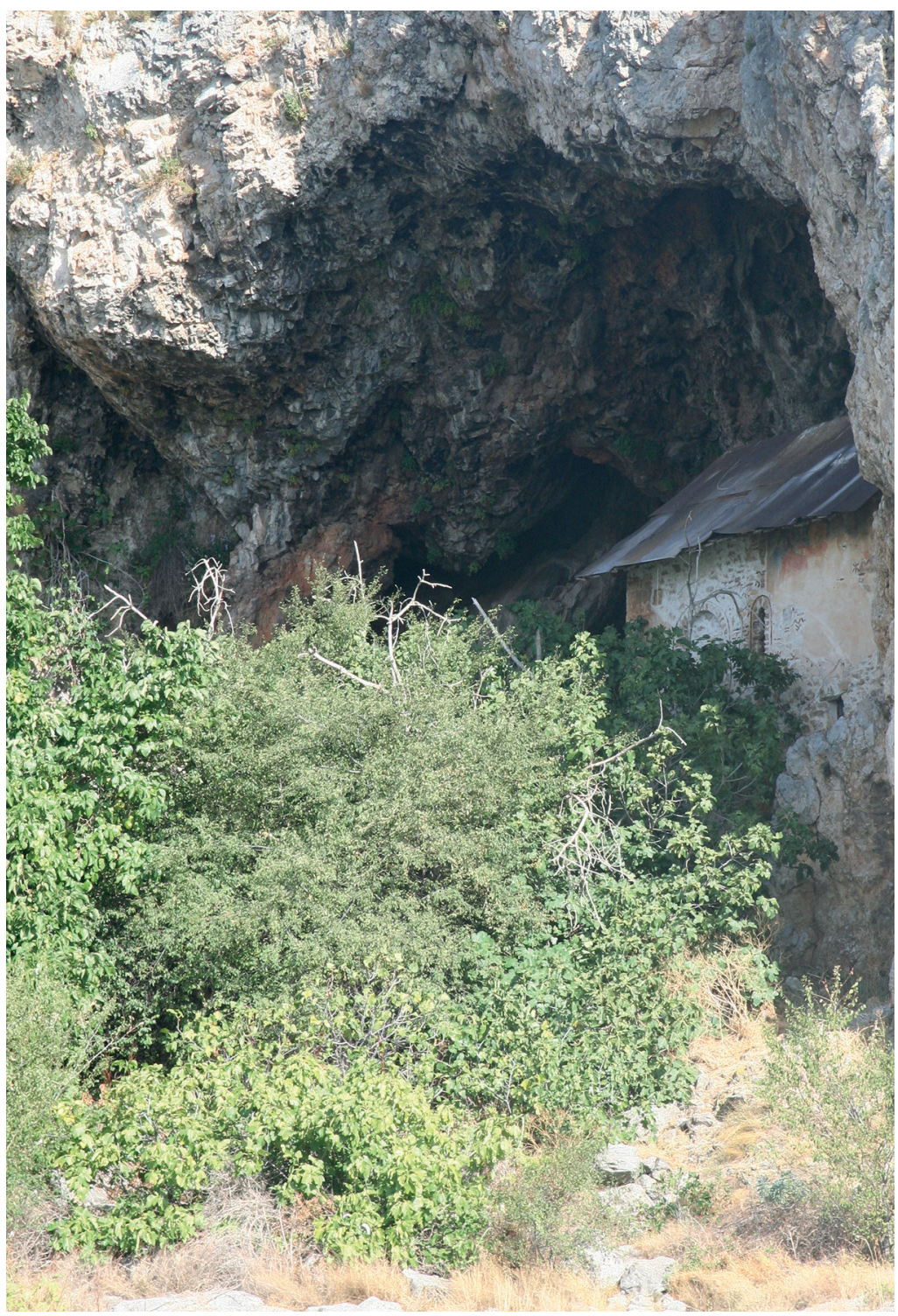

Pic. 1. Maligrad Island, Great Prespa Lake, Albania. September 2008. Photo by A.A. Novik

way (due to natural conditions), then its fruits are less used in local cuisine. However, even when the fig tree does not grow at all in certain areas (primarily in mountainous areas, with a lack of humidity, etc.), its fruits are still eaten in the diet of residents due to the well-established tradition of nutrition (involving the use of dried fruits in winter) and trade links from the antiquity times that ensure the delivery of food to the most distant places (Gjergji 2002: 46-47; Golant 2020). Fresh and dried figs are present on the table of the Western Balkans inhabitants almost all year round. The greatest varietal diversity is recorded in the coastal and lowland areas of Albania, where figs are harvested from the beginning of June to the end of October (AMAE 2019). Fruits of different shades of green, yellow, brown, burgundy, purple differ in size, sugar content and taste. 


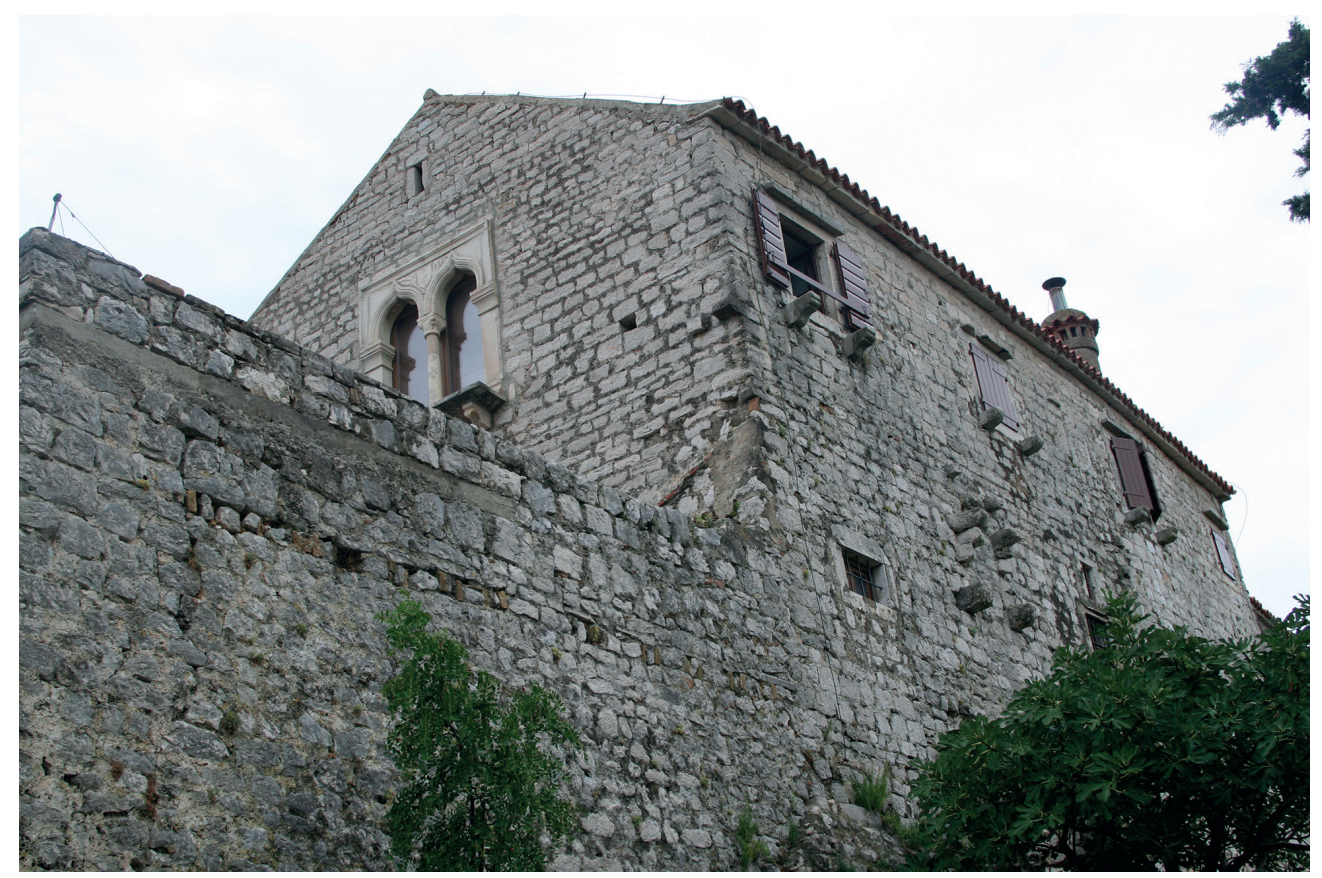

Pic. 2. The fig tree near the walls of the monastery of St. Cosmas and Damian. Mount Chokovac, Pašman Island, Croatia. September 2016. Photo by A.A. Novik

In the beginning figs like this ripen here - eggplant-colored fruit. Some very large, some medium-sized. We sell them already in June: we take them to the market or to the side of the road, where cars drive by. It is one of the first fruits to ripen. People are willing to buy, because they have already missed it over the winter. We will start making the jam later, in August-September, when other varieties are ripe. In the meantime, we need to earn money (FMA 2018: inf. Albanian, 54, Elbasan, Albania; interview recorded in Albanian in June 2018).

The further north you are from the Ionian and Adriatic coasts of Albania and the further into the inland depths of the Balkan Peninsula, the less diverse the types of fig trees and ways of using them become. Thus, the Croats of the islands of Pašman and Ugljan in Dalmatia cultivate mainly one kind of fig tree, the fruits of which, small but extremely sweet and tasty, ripen in September. Locals consider this variety to be endemic and are extremely proud of it:

Our figs ripen late in the year, only in autumn. But they are delicious. Over there in the south, they are harvested early. But they are not that tasty. We have the best figs in Croatia and in the whole region! You will find a fig tree near every house, and we plant it out in the streets. If someone is on the street and picks the fruit, it is not of great importance, the main thing is that they should not take the whole crop away. Although this never happens here. The road to the monastery is also planted with fig trees ${ }^{8}$. There the pilgrims pick the fruits (AMAE 2016a: inf. Croat-Dalmatian from Pašman Island, 67 years old; interview recorded in Croatian on Pašman Island in September 2016).

The Arbnesh people in Zadar (Dalmatia, Croatia) perceive the fig tree as a symbolic fruit tree for the community. Descendants of the Albanian Catholic settlers who moved to this region in 1726-1733 from the territory of the present borderland of Montenegro and Albania in the area of Skadar Lake (see: Krstić 1988; Stipqeviç 2012: 1-3), cultivate the fig 


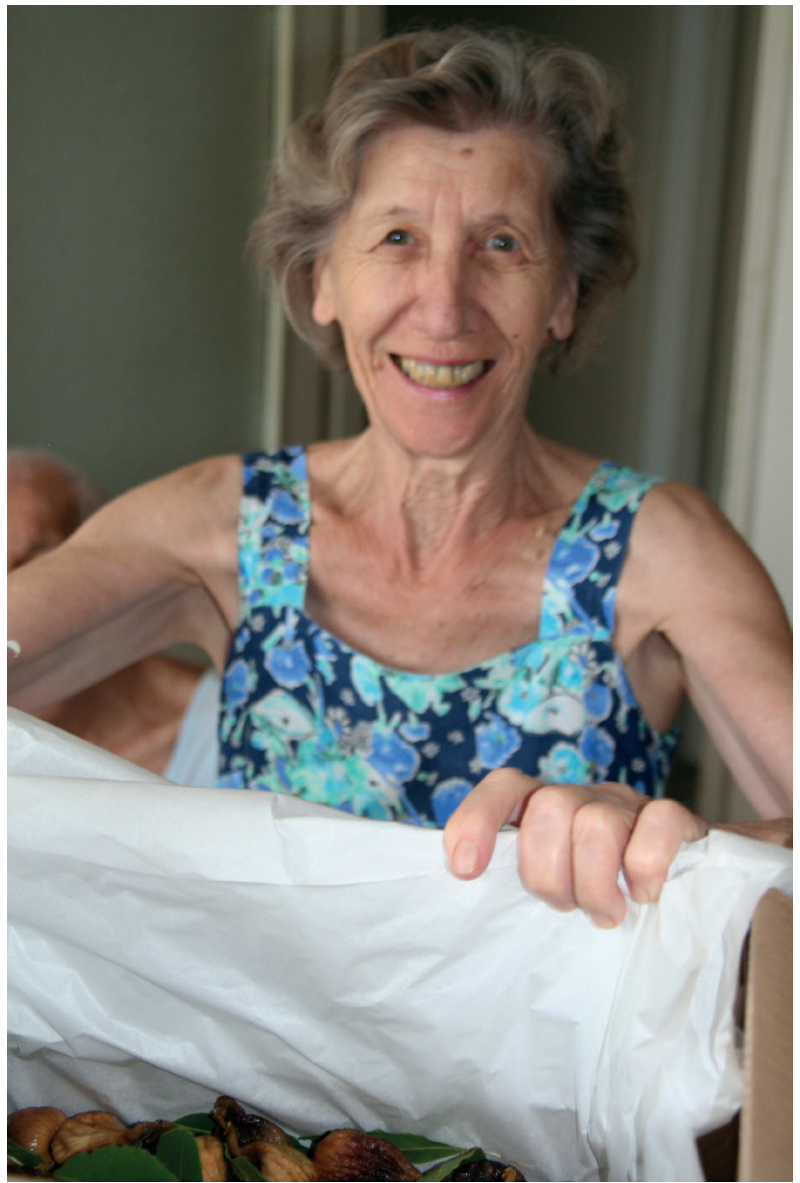

Pic. 3. An Arbnesh woman, informant of the expedition, with the fruits of a fig tree. Arbanassi quarter, Zadar, Croatia. September 2016. Photo by A.A. Novik

tree right in the city limits to this day, thus carrying on a very long tradition. The Arbanassi residential quarter, allocated to the settlers by the ecclesiastical and secular authorities of the Venetian Republic in the immediate vicinity of the Old City, was supposed to supply the townspeople with fresh vegetables and fruits throughout the year (Stipqeviç 2012: 3-5; Novik 2017: 133-136). On the allotted land, the Arbnesh set up vegetable gardens, planted olive groves, and planted fig orchards and vineyards next to residential buildings. During the time that has passed since the first third of the 18th century, a lot has changed in the economic structure of the residents of the quarter (in the second half of the 20th century, there happened a refocusing to the tourism sector). However, fig trees in the yard of their own home are a manifested and obvious marker of Arbnesh identity (see Pic. 3).

An Arbnesh will always have a fig tree growing in the yard. This is how our ancestors started it all. We, the Arbnesh, are the only ones to have the secret of the proper drying of figs. Croats do not know this. We collect the fruits, then we put them in the pickle-juice. We prepare this pickle-juice: we boil water and pour salt into it. When it boils over, we cool the resulting brine and put the fruits in it. And only then do we begin to dry them. After processing the fruits in the brine, not a single fly will dare to sit on them. Others here in Dalmatia do not know this. They dry figs directly from a branch, flies sit on them by swarms, lay larvae, then worms 
appear. They can't it, at all! Probably, this secret was also brought by our ancestors from Albania (AMAE 2016a: inf. Arbnesh woman from Arbanassi quarter, Zadar, 66 years old; interview recorded in Arbneshi in September 2016).

The adherence to tradition is also confirmed by the fact that fig trees grow even in the yards of the few apartment buildings erected in the quarter in the post-war years, and in September, rough-and-tumble tables with fruits drying after processing in the brine appear. By the way, dried figs is one of the favorite delicacies for adults and children throughout the region, regardless of their ethnicity and religion.

In the west of the Balkans, sweets obtained as a result of boiling fig fruits are also popular. Depending on the technology, three main types of product are prepared from the same ingredients: 1) jam (the fruits are completely boiled soft in sweet syrup to a homogeneous texture); 2) preserves (fruits retain their original shape). Note that fig preserves are popular among the southern Slavs and their neighbors, and among the Albanians for many years it remains the most widespread of this kind of "sweet stuffs"; 3) marmalade (more homogeneous, thicker mass) (Reçel fiku 2020).

In the Albanian language, various nominations for these types of product are recorded: reçél, - $i$ - "jam” (< Turkish reçel - "jam”), likó, -ja = glikó, -ja - "jam” (< Modern Greek

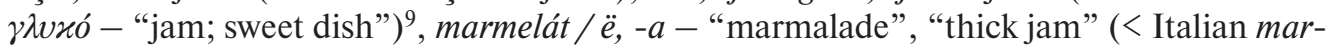
mellata - "jam" < Portuguese marmelada < marmelo - "quince fruit") (Kostallari 1980: 1059, 1638; Newmark 2000: 464; Ymeri 2005: 195; Topalli 2017: 941). And this terminology is very stable in dialects, and contamination, when jam is called preserve, and preserve is called jam, are practically not recorded. Among the southern Slavs (Croats, Serbs, Montenegrins, Bosniacs, Macedonians, Bulgarians, etc.), different types of jam

are often denoted by the generalizing lexeme slatko/sladko (see, for example: Tolstoy 1957: 881; Chukalov 1960: 1015; Usikova, Verizhnikova 2003: 638). This, for example, is the case in the language of the Muslim Slavs of Golobordo/Golo Bordo (Eastern/Northeastern Albania) (Sobolev, Novik 2013).

The Vlach-ţărani of the Timok Valley (Eastern Serbia) (see about the Vlachs of the region: Sikimić, Ašić 2008) eat only fresh figs. The limited practice of making jam (Vlach. slatko de smochine) among this ethnic group is evidenced by at least the fact that in the village of Shipikovo, according to our informants, only one local resident knows how to cook it. "The cooking process is considered difficult and time-consuming, few people want to do it" (Golant 2020). It is not customary either to dry or sun-cure figs here, although everyone knows that it is prepared in this way in Montenegro. We are not talking about the ritual use of the wood of the fig tree. At the same time, according to the founder and director of the Shipikovo Ethnographic Museum Ventsislav Duinovich, Vlachs in this village and surrounding villages (Mali Jasenovac, Veliki Jasenovac, Halovo) belonging to the Zajechar community, as well as in the village Rabrovo on the territory of Bulgaria (Vidin region, Bojnica community) pay more attention to the cultivation of fig trees than Serbs living in the neighborhood (the villages of Brachevac and Rayac, Negotin community, Eastern Serbia), in whose farms they do not grow figs at all, and, accordingly, do not process the fruit (AMAE 2017; Golant 2020). The informants explain this situation by the fact that

[the fig tree] growing here in bush form, is generally not adapted to the local climate (Golant 2020: inf. Mirjana Duinovich, Vlach, born 1958, village Shipikovo, Zajechar district, Serbia; interview recorded in Vlach in 2020).

In Eastern Serbia, the fig tree grows, but not everyone plants it, and some often have only one or two trees. The climate in the Timok Valley is not very favorable for it, and here it is considered a very intricate tree. They try to plant it in places protected from the wind, and in winter they cold-proof it with sheaves of corn stalks or with nylon. There are varieties that 


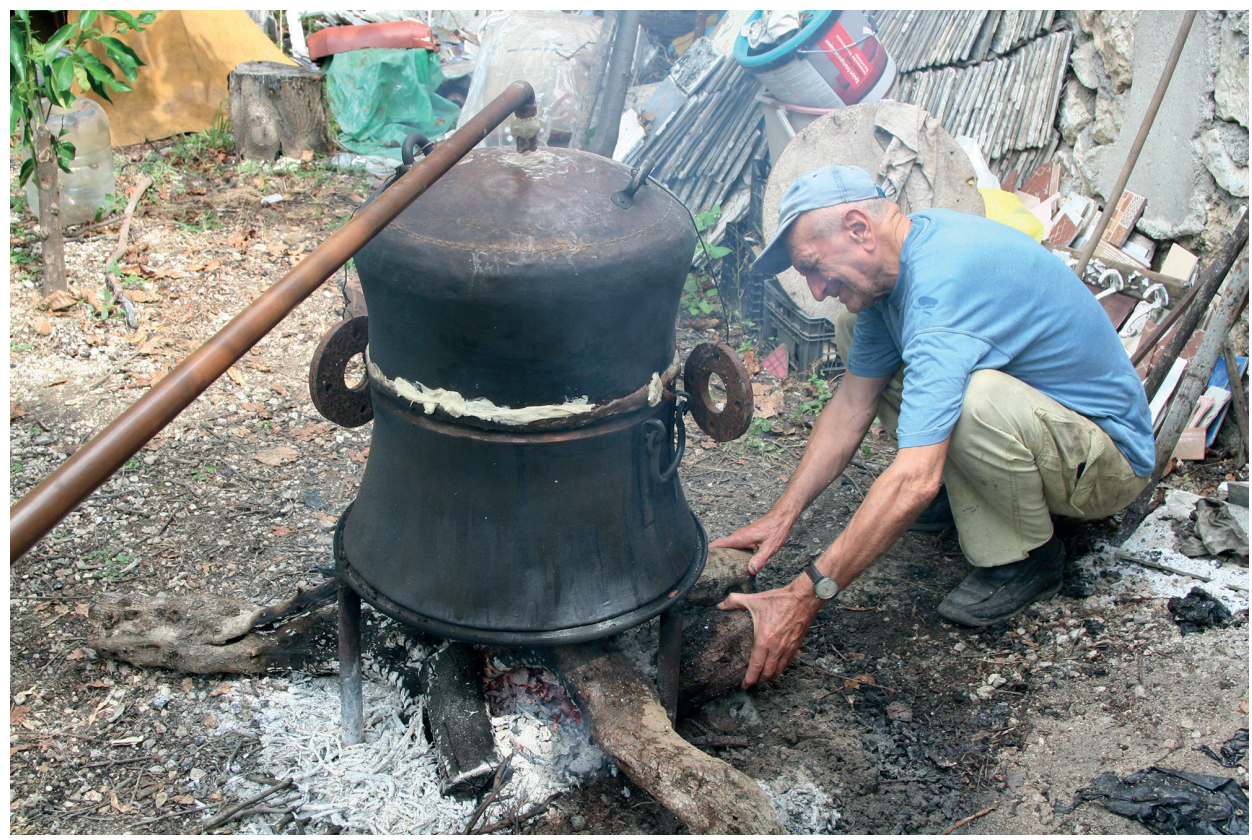

Pic. 4. Michalis Lyalutsis, informant of the expedition, making rakia. Paljasa village, Himara, Albania. September 2019. Photo by A.A. Novik

produce two crops per year (Golant 2020: inf. Ventsislav Duinovich, Vlach, born 1972, village Shipikovo, Zajechar district, Serbia; interview recorded in Vlach in 2020).

Under the influence of oriental culture during the Ottoman rule in the Balkans, pekmez/ pekmes (Alb. pekméz, -i, pekmés, - $i$; Bulgarian petmez; Serbo-Croatian pekmez < Tur. pekmez $<$ Pers. bekmaz), a highly boiled syrup from all kinds of berries and fruits entered the cuisine of local nations (Kostallari 1980: 1395; Dizdari 2005: 759; Meyer 2007: 374). The most common are grape pekmez and fig pekmez. Note that today in Albania, the former is cooked less often than the latter. In this case, the following technology of traditional production of pekmez is most often used: squeezed grape juice or mashed figs passed through a large sieve is placed in a cauldron, put on fire and, with constant stirring, cooked for about five hours until the mass thickens significantly. The resulting viscous syrup is considered a delicacy product with exceptional taste, it cures liver and gallbladder diseases, and is an excellent remedy for scurvy, etc.

I try to collect the entire fig crop as soon as possible and make pekmez from it. We have a lot of figs, so it is impossible to eat them as it is in the family. And I won't be able to sell the whole crop - in our district there are many trees growing in every yard. My husband, if I don't have time to harvest the crop quicker, will immediately put the figs for the brandy. And then he will drink all year through. I guess grapes are enough for him! Therefore, I quickly collect (fig fruits $-A . N$.) and set the pekmez to cook. We eat it at home in winter, add it to sweets, baklava, and so on. And I also sell it, here, right on the highway, next to the house. The price is good and the revenue is big.

There is a lot of fuss with this pekmez. It takes a long time to cook it. And if you cook, you have to stir it continuously, otherwise it will burn. And cool it in the proper way, then pour it out. It takes a whole day for one batch. But all the work pays off. Do you know how useful it is? After all, people are not in vain willing to pay big money for it. It's not just fig jam there. 
This pekmez is the first remedy for black liver disease ${ }^{10}$ (AMAE 2013b: inf. Albanian Muslim woman from Labinot-Fushë, 43; interview recorded in Albanian in September 2013).

Among the peoples of the Balkan Peninsula, the distribution of pekmez correlates with confessional affiliation. Most often it is prepared in the houses of Muslims, whose oriental cuisine is preserved quite steadily: among Bosniacs, Muslim Albanians (Sunnis and Bektashi), Muslim Macedonians, Pomaks, Turks, etc. In general, this fact reflects the level of adaptation oriental culture and cuisine as part of it in the vast region of South-Eastern Europe (on the adaptation mechanisms of foreign cultural realities, including the food system, see theoretical works: Arutyunov 1981: 3-11; Bart 2018).

We can also point out the marginal uses of figs in the cuisine of the Western Balkan peoples. Thus, they make a drink like surrogate coffee or chicory from dried figs of poor quality (Mitrushi 1955: 454). To do this, the fruits are ground in a mill, poured with boiling water and allowed to brew or boiled in a Turk (Turk. cezve). In the past, in poor families, such a drink replaced coffee (it was also served to guests), and now it is drunk by those who cannot drink coffee for health reasons. Fig fruits are useful for a number of diseases: respiratory tract, digestive tract, heart, circulatory system, etc. (Sulaj 2013: 94; AMAE 2019).

In winemaking, figs are used in the production of rakia (Alb. raki, -ja; Serbo-Croatian rakija, rakijca; Bulg. раки́я; Rom. rachie, rachier; Modern Greek $\rho \alpha x i<$ Tur. rakı < Arab. arakijjá) - an alcoholic drink obtained during the distillation of fermentation products of fruits of various plants (Chukalov 1960: 961; Kostallari 1980: 1632; Dizdari 2005: 831-832). Traditionally, rakia is made from berries (including grapes) and fruits containing a fairly high percentage of sugar required for a stable fermentation process (often the resulting drink is additionally infused on various fruits and herbs; for example, the Turks, Greeks and Bulgarians widely use anise to give it a pronounced aroma). The most widespread raw materials for rakia in the Western Balkans are grapes and plums; quinces, pears, mulberries, persimmons, apricots, dogwoods, etc. are used to a lesser extent. In principle, rakia can be made from any sweet fruit, but the Balkans have quite strong stereotypes concerning what this drink can be made of. Thus, figs, despite their wide and long-term distribution in the region and an exceptionally high level of fructose, have won a niche in the second or even the third "division" of plants that provide raw materials for rakia (see Pic. 4). According to the key informants we interviewed in all countries of the studied region during the expeditions of 1990-2019, fig rakia "turns out to be too intoxicating", "causes a severe hangover", "a very strong potion", "you can get drunk", etc. (FMA 1990; AMAE 2015, 2019).

In fact, figs are the best raw material for rakia. Fig fruits produce the strongest drink. And it grows everywhere here, it does not require special care. It always yields a good crop. It produces harvest every year, not like some other trees - every other year. Just make rakia as much as you wish! And it's nice to drink it, it comes out mild. And a subtle aroma from it $<\ldots>$ But here it is not particularly appreciated. We are a rich region, we have always had high requirements. We traded with Corfu, with Italy, even with Palestine ${ }^{11}<\ldots>$ And we always had grape rakia in the first place. The grape one needs to be served to guests. And from figs, only for yourself, or with one of your closest friends you can drink (AMAE 2019: inf. Greek, 85 years old, Paljasa village, Himara, Albania; interview recorded in Greek in Palasa village in September 2019).

The peoples living in the west of the Balkan Peninsula differ not only in the level of adherence to traditional attitudes in the food system, but also in the degree of openness to innovation. Thus, the southern Slavs (Serbs, Croats, Montenegrins, Bosniacs, etc.) are more inclined to adhere to long-established rules and stereotypes, they have widespread rakia from grapes - lozova, plums - šljivovica, quince - dunjevača and from pear variety Williams viljamovka; all other types of drink are perceived as complementary and optional. Albanians, on the other hand, are inclined to experiment and produce rakia from literally any plant 
material containing fructose and sugar. The factors that determined this difference are: firstly, the centuries-old regional fragmentation into provinces, in which local types of farming dominated, depending on climatic characteristics, and, consequently, local food attitudes, and secondly, the closed nature of Albania during the years of socialism, forcing the peasants to produce the necessary food and drinks in an old-fashioned way from everything that was available (see: Gjergji 2002). Thus, unlike their neighbors, the Slavs, Albanians make rakia not only from grapes (most often) and plums (relatively rarely), but also from all possible fruits and berries that grow in places of residence: from figs, mulberries, persimmons, etc. Skrapar is considered to be the most famous land in Albania producing rakia; the raki Skrapari made here (almost always from grapes) is a strong regional brand. However, no less popular is mulberry rakia from the village Boboshtica (Korçë district, Southeastern Albania) - to make it, trees are specially planted here that produce green fruits (FMA 2019).

Interethnic borders in the Balkans determine, among other things, the areas of production and consumption of fig rakia: the Albanians and, to a lesser extent, the Greeks preserve the tradition of its manufacture, while among the Slavs it is extremely rarely recorded. Confessional affiliation plays a role in the spread of this practice (as well as in the consumption of alcoholic beverages in general). Thus, $40 \%$ of the population of Kosovo, according to statistics, have never tasted alcohol in their life (Agjensia e Statistikave n.d.): in most Albanian households, rakia is not made at all, but its production is widespread among local Serbs (most often it is rakia made from grapes and plums, as among Serbs in Serbia). However, the Bosniacs of Bosnia and Herzegovina, as well as, for example, Muslim Albanians and Muslim Slavs of the Mrkojevići tribe in Montenegro and their neighbors professing Christianity (both Orthodoxy and Catholicism), do make rakia (AMAE 2009, 2013a, 2016b). Accordingly, based only on the confessional principle, we cannot argue that there is a distinction in the practice of consuming fruit and berry rakia, since the Slavs in the west of the Balkans (as well as throughout the peninsula) profess different religions, as well as their Albanian neighbors. The presence of the identified isodoxa and isopragm of the existence of rakia, its production and consumption between the two ethnic areas is explained precisely by the attitude towards the preservation of the drinking tradition, the maintenance of an established nutrition system, as well as the susceptibility to innovations in this area. What unites all the peoples of the Western Balkans is a common rejection of the breakdown of the food paradigm, dictated from the outside (Sobolev, Novik 2013: 221). Thus, almost all of the interviewed informants spoke about the superiority of rakia (not so important, traditional or not previously typical for their area) over other strong alcoholic beverages: vodka, gin, whiskey, rum, etc. made not from fruits and berries, but from wheat, corn, sugar, etc. and not corresponding to the established taste preferences, primarily due to the other composition of raw materials, the nature of fermentation and production technology. As an example, here is a part of an interview recorded with the Muslim Slavs of Goloborda/Golo Bordo (Eastern/ North-Eastern Albania) during the Balkan expedition of the Russian Academy of Sciences and St. Petersburg State University in 2009:

We are used to our rakia. Every man in our country starts the morning with a glass of homemade rakia. First rakia, and then coffee, and after coffee you can have breakfast that's how we go about it. Then, during the day, we also drink a few glasses. How much exactly? Well, six-seven. This does not prevent us from working. After all, each family has an allotment of land, livestock, a lot of work. But not even one day can go by without rakia. It is delicious here. And your vodka is probably good, but not for us. It has a different taste, a different nature. Our rakia is based on grapes or dogwood or something, whatever. And what about vodka? Sugar? Bread?! Bullshit! That is why it somehow does not suit us. We drink what our grandfathers drank (AMAE 2009: inf. Muslim Slav from Goloborda, 
Trebisht village, Albania, born in 1953; interview recorded in Macedonian dialect in September 2009).

As for low-alcohol drinks made from figs, they are practically not recorded in the Balkans. In recent years, in the west of the Balkans, along with traditional grape wine, the production of fruit and berry wines from blackberries, pomegranates, etc. has become popular. They began to be made both in households and in factories, trying to meet the growing demand and paying tribute to the European fashion for environmentally friendly products and at the same time to the exotic in the food sector (Produktet tona n.d.). Figs were not included in the list of such innovations, primarily because the specificity of fermentation of its fruits does not guarantee the transparency of the drink and its proper preservation. It remained only a raw material for a strong alcoholic drink - rakia. But here, too, the sphere of distribution of figs is limited by a small triangle between the coasts of the Ionian and Adriatic seas and the North Albanian Alps.

In cheese making, the fig tree also is applied. It is known that fig tree milky juice has coagulating properties and has long been used as a clotting enzyme in the manufacture of cheeses. Columella wrote about receiving it in the 1 st century AD: ...ficulno lacte, quod emittit arbor ("...having cut the bark of a fig tree, they got "fig milk" ") (Col. R. R. 7. 8. 1; cited from: Grosheva 2011: 119). Nowadays, this technology is practically not registered in the Western Balkans. But in recent decades, dried figs have been actively added to readymade rennet cheeses. This fact should be recognized as a tribute to fashion that dictates the demand for food exotic and forms the supply: cheeses with walnuts and hazelnuts, hot peppers, olives, etc. Much of this strategy is inspired by trends in global trade: innovative food production methods force manufacturers to use imagination and ingenuity. Local varieties of cheese with pieces of dried figs can be found in Albania, Montenegro, Croatia, and other countries of the region, where the fig tree is widely cultivated and holds a firm place in the culinary code of the population. At the same time, it must be recognized that most of the cheese with figs is produced, as a rule, in small factories, and the share produced by household peasants or farms is quite insignificant.

As an ornamental material, fig tree is practically not used. "The wood of figs is not very strong - it is porous, so it is not used in joinery" (Golant 2020). The dried branches and trunk of the fig tree are used as firewood for cooking and rakia production. "This wood is not durable. We take the branches as brushwood and put them into the fire! Previously, collecting them was the responsibility of children. And now, the one who found it carries it into the yard" (AMAE 2019). In Croatia and Montenegro, fig tree wood is sometimes used to make souvenirs for numerous tourists, but in this area, demand determines supply, so figs have serious competitors on the market: olive and juniper are considered more valuable, and products from them are sold at a higher price.

\section{Figs in Traditional Medicine: From Prejudice to Bio resource}

In traditional medicine of the Balkan Peninsula countries, the fig tree has been used for a long time. In particular, in Albania and Bosnia, the milky juice of unripe fruits is used as a laxative and anthelmintic (Glück 1892: 163; Mitrushi 1955: 454; Lafe 2008: 676; Sulaj 2013: 94), while Croats, on the contrary, previously used it to fix bowel problems, for which ripe fruits were ground with honey ( ̌̌lek 1879: 364).

The fig tree is known to be helpful in relieving liver and spleen problems. We have already talked about the use of fig pekmez for the treatment of liver diseases in Albania above. And in the old Croatian medicine book, it was suggested to grind the root of the fig tree, boil barley flour with it and apply na rast, i.e. into the area of the swollen spleen ( $\breve{S u l e k}$ 1879: 364). Among the Serbs, those figs that remained after Christmas Eve (Badnidan, January 6) were considered especially healing. These fruits were considered extremely 
effective for the treatment of coughs and colds, sore throat, as well as for wounds and scabs. It was believed that the juice of fresh figs helps with scorpion bites (Chaykanovich 1985: 220). In Albania, as we have already noted, the milky juice of unripe fruits and dried figs were used to treat the respiratory tract, for cough, etc. (Sulaj 2013: 94).

In Bosnia, a healing ointment was prepared from dried figs with the addition of mallow leaves, spruce resin, salt, soap, yolks and milk. It was applied to syphilitic ulcers. Fresh fruit juice was used to relieve inflammation and pain aftera strong blow. Fresh and dried figs were rubbed onto the face to preserve beauty. And now, for the treatment of chest catarrh (acute respiratory disease of the upper respiratory tract), it is recommended to chew ripe figs; they are also used for sore throat (rinsing with water decoction) (Glück 1892: 163).

The fig tree was used not only in rational healing, but also in the magical practice of destroying the disease, where metaphoric actions played an important role. For example, in Greece, it was believed that the branches of the fig tree facilitate childbirth. The midwife brought a fig tree branch with three sprouts (the sacred number three, the number of the Trinity) to the woman and began to chop them off, pronouncing incantations three times. Chopping off meant the symbolic destruction of pain (Sidneva 2008: 137-138). The image of a fig tree was also used in the incantation to add milk for a nursing woman: "How much milk a fig has, let the woman in labor have the same amount of milk. As the fig opened, let the veins of her breast also open". Since the white juice secreted by the fruit of the fig tree was compared with the milk of a woman, it was prohibited to heat the stove with fig tree wood or chop it while the woman was feeding the baby, otherwise the mother would not have milk (Ibid: 138).

At the beginning of the XXI century, the fig tree remains an important element of both the food culture and the healing system in almost all, without exception, countries of the Western Balkans. The extreme popularity of figs has been strengthened in recent years by the fashion for organic products and the passion of a significant part of society for healthy eating: followers of the ideologies of vegetarianism, veganism, fruit-eating, separate nutrition, etc. consider figs to be extremely useful (VegaGo.ru s.a.). Numerous varieties of fig trees, providing harvest from early June to late September, make it possible to eat "healthy fruits" almost all year round - fresh in the summer and autumn season and dried in the winter and spring (AMAE 2019).

Figs, long and firmly rooted in the diet of most Balkan peoples, in the last two decades have been perceived as an integral component of "proper" nutrition, which is the result of the development of the "global megatrend of health", popularized in the information space and successfully sold as an "achievement" of modern civilization. This situation in the Balkans is reinforced by the extremely high prestige of the Western culture and the Western way of life, which are perceived - after a long period of destabilization, conflicts and a shift in socio-political paradigms - as an immutable life guide and role model. In turn, for the Western alimentary system, the culture of consumption and, most importantly, the way of thinking, turning to organic food products - preferably grown in the consumer's region of residence, relying on the traditions of local food - becomes a kind of ide fix, very easily transmitted and borrowed due to the global nature of information links.

The concept of the superiority of organic matter and environmentally friendly products, the traditional way of life and the "return to the origins of the culture of the ancestors" are inextricably linked to the awakening of mass interest in quackery and the turning to traditional medicine. Until the twentieth century, treatment with herbs, potions, recourse to magical practices, etc. remained for the majority of the world's population the only way to survive in conditions of limited resources, primarily professional medicine and its availability. By the end of the last century, the economic and social development of the western countries of the Balkan Peninsula made turning to certified specialists and obtaining the necessary assistance quite common practices for the bulk of the region's inhabitants (while in the countries that were building socialism, the free provision of all medical services 
was declaredand often observed; their quality is not currently being discussed). This weakened the position of healers and sorcerers for several decades. Traditional medicine and quackery began to rapidly return to the Balkans in the early 1990s. In this process, the unconditional attractiveness (in the era of high technologies and scientific progress!) of the magical component of medicinal practices is extremely important, which is facilitated by the same technologies and the global information space (see: Adamou, Matras 2021). Paradoxical as it may seem, but precisely during the widespread dissemination of technical innovations and unconditional progress in the field of medicine, many people tend to look for a panacea for all diseases and misfortunes in traditional methods of healing, herbal treatment, a return to healers' methods, mythical rituals, etc. (cf.: Kharitonova 2006). In any case, turning to healing and belief in the supernatural have become a kind of trend of our time, which can be described as "it's better to believe in anything than not to believe at all".

In this context, the fig tree accidentally took a very advantageous position. On the one hand, its fruits have always been included in the diet (fresh and dried figs, syrups, alcoholic beverages, etc.). On the other hand, various parts of the plant and fruits of different degrees of maturity were used in traditional medicine of different nations, sometimes for the treatment of completely opposite symptoms (see an example above). Thirdly, the wood of the fig tree was an indispensable attribute of ritual practices and rituals, often the most important ones (as among the Albanians). And the role of figs in the economy is a marker that previously allowed and still allows today the residents of different regions of the Western Balkans to draw a conditional border between us and them, (Croats of Dalmatia and the Arbnesh of Zadar, Serbs and Vlachs of Eastern Serbia, Greeks and Albanians of Himara and others), focusing on the depth of plant penetration into culture.

The endowment of the fig tree with new meanings occurs against the backdrop of a global passion for Bio products, a turning to folk medicine and magic, the maintenance and revitalization of traditional practices and the construction of life and consumption according to the principle of ecological purism with its slogans: "closer to nature", "only organically pure", "we consume only what our ancestors ate", etc. Plants, fruits, seeds and other components of the flora world have become in this game a trump card in reshaping resources: people tend to blindly believe the prophets from medicine and trust Bio, that is, produced by nature, more than anything created by man, i.e. modern food industry, transnational pharmaceutical giants, world science and the global information system. Residents of all the studied countries of the Western Balkans, as a rule, do not believe in propaganda and advertising of all kinds of goods and medical services, except - and this is paradoxical! advertising of organic food, promotion of a healthy lifestyle and calls to "return to the traditions of ancestors" in the field of organizing life and consumption. That is why the demand for medicines from the pantries of nature and for local foodstuffs is growing from year to year; more and more money and resources are flowing into this market segment, and the usual and once not particularly appreciated fruits and plants suddenly turn out to be "an incomparable and irreplaceable source of nutrients, essential elements and vitality". Not only healers, traders and farmers, but also industrial giants, pharmaceutical corporations and the global information industry are trying to earn reputational and real capital on the exploitation of the truths as old as the hills.

\section{Notes}

${ }^{1}$ Due to the long tradition of mentioning the fig tree and its fruits in written sources, many almost complete synonyms have formed in the Russian language to name them. The question of the origin and stylistic load of these synonyms is outside the scope of this work. The authors use the following terminology into Russian: for a tree (Ficus carica) - “фиговое дерево”, “смоковница”, “инжир”; for its fruit - “смоква”, “плод смоковницы”, “фига”, “инжир”. 
${ }^{2}$ Pliny the Elder describes this plant as follows: “...a fig that never reaches maturity is called wild" (Lat. caprif ìcus vocatur... fìcus numquam maturescens) (Plin. Nat. 15. 79).

${ }^{3}$ By the way, K. Linnaeus was the author of the names of a number of botanical taxa, and in the botanical (binary) nomenclature these names contain the abbreviation "L." - from "Linnaeus".

${ }^{4}$ The question of applying the name caprificus "wild fig" to a male tree remains outside the scope of this article. We will only point out the general evaluative component of the naming goat = nonfertile, i.e. only omnivorous goats could eat those inedible for humans fruits, which were produced by the wild fig tree.

${ }^{5}$ Zana (Alb. Zán/ë, $-a$ ), as well as Ora (Alb. Or/ë, $-a$ ) - mythological characters in the beliefs of the Albanians, guardian spirits of a place, area, natural object, an individual representative of the flora or a whole grove, as well as a person, family, community, village, land and the whole country. In different regions, the roles of Zana and Ora can change, so there is a significant polysemy of characters and their nominations (Tirta 2004: 57-61, 111-121, 181-186).

${ }^{6}$ Samuil - the king of Bulgaria (980-1014) from the Komitopul dynasty.

${ }^{7}$ Lagja (Alb. lágj/e, -ja) - a district, quarter of a city or village (Kostallari 1980: 936), in Dukagjin nowadays it is often a remote small settlement, administratively related to a larger settlement.

${ }^{8}$ In fact, on the sacred Way of the Glagolitic (Croatian Glagoljaški pat; the name goes back to the Glagolitic alphabet used in liturgical books), the road of Catholic pilgrims to Mount Chokovac and the Benedictine monastery of St. Cosmas and Damian (XII-XIV centuries) near Tkon on the Pašman island (see Pic. 2), there are not many fig trees, mostly the sides of the steep walking path are overgrown with blackberry bushes.

${ }^{9}$ The significance of the product for the institute of hospitality can be judged at least by the fact that G. Mayer in his "Etymological Dictionary of the Albanian Language", first published in 1891, gives a rather inaccurate meaning of the word: "glikó "reçel 'jam', to treat during visits"” (Meyer 2007: 173).

${ }^{10}$ Alb. mëlçí e zëzë, lit. "black liver" is a colloquial variant of the literary mëlçí, - $a$ "liver" (Newmark 2000: 526).

${ }^{11}$ See about v. Palasa: Joseph et al. 2019; Billa 2020.

\section{Abbreviations}

Col. R. R. - Columella. De Re Rustica.

Plin. Nat. - Plinius Maior. Naturalis Historia.

\section{Sources and materials}

Agjensia e Statistikave n.d. - Agjensia e Statistikave të Kosovës. Ask. https://ask.rks-gov.net (access date: 25.12.2020).

AMAE 2008 - Novik A.A. Muslim Macedonians in Albania. 2008. Archive of MAE RAS. K-1, op. 2. No. 1863.

AMAE 2009 - Novik A.A. Traditional culture of the Goloborda Macedonian Muslims (Eastern Albania). 2009. Archive of MAE RAS. K-1, op. 2. No. 1938.

AMAE 2013a - Novik A.A. Montenegrins of the Mrkojevići tribe. 2013. Archive of MAE RAS. K-1, op. 2. No. 2175.

AMAE 20136 - Novik A.A. Expedition to Toskeria. 2013. Archive of MAE RAS. K-1, op. 2. No. 2177.

AMAE 2015 - Novik A.A. Albania. Traditional culture of Albanians in Albania, jewelry, Albanians and Slavs. 2015. Archive of MAE RAS. K-1,op. 2. Temp. w/n.

AMAE 2016a - Novik A.A. The Arbnesh of Zadar, Croats, Slovenes. Dalmatia, Croatia. 2016. Archive of MAE RAS. K-1,op. 2. Temp. w/n.

AMAE 20166 - Novik A.A. Montenegrins of the Mrkojevići tribe. Catholic Albanians and Muslim Albanians. 2016. Archive of MAE RAS. K-1,op. 2. Temp. w/n.

AMAE 2017 - Novik A.A., Golant N.G. Ethnolinguistic expedition to the Vlachs (Romanians) of Eastern Serbia. 2017. Archive of MAE RAS. K-1,op. 2. Temp. w/n.AMAE 2019 - Novik A.A. Expeditionary work in the zone of Greek-Albanian contacts (Southern Albania, Himara). 2019. Archive of MAE RAS. K-1,op. 2. Temp. w/n.

André 1956 - André J. Lexique des termes de botanique en latin. Paris: Klincksieck, 1956.

Billa 2020 - Billa K. Palasa - sa afër dhe sa larg. Vlorë: SAI, 2020. 
Chaykanovich 1985 - Chaykanovich $V$. Dictionary of Serbian folk beliefs about plants. Belgrade: Serbian Academy of Sciences and Arts, 1985.

Chukalov 1960 - Chukalov S. Bulgarian-Russian dictionary. Sofia: State Publishing House "Science and Art", 1960.

Common fig s.a. - Common fig, or fig tree - Ficus carica. Ecosystema.ru. http://ecosystema. $\mathrm{ru} / 07$ referats/cultrast/159.htm (access date:20.12.2020).

Dizdari 2005 - Dizdari T.N. Fjalor i orientalizmave në gjuhën shqipe. Tiranë: Instituti Shqiptar i Mendimit dhe i Qytetërimit Islam; Organizata Islame për Arsim, Shkencë dhe Kulturë, 2005.

FMA 1990 - Field materials by A.A. Novik. Bulgarians in Bulgaria. Albanians in Kosovo and Macedonia. Serbs in Kosovo. Macedonians in Macedonia. 1990.

FMA 1996 - Field materials by A.A. Novik. Albania. Dukagjin. 1996.

FMA 2008 - Field materials by A.A. Novik. Albania, Macedonia, Lake Prespa. 2008.

FMA 2011 - Field materials by A.A. Novik. Bosnia and Herzegovina, Mostar. 2011.

FMA 2018 - Field materials by A.A. Novik. Albania. Kosovo. Macedonia. Montenegro. 2018.

FMA 2019 - Field materials by A.A. Novik. Albania. Kosovo. North Macedonia. Romania. Montenegro. 2019.

Frazer 1990 - Frazer J.J. Folklore in the Old Testament. Moscow: Publ. house of political literaturte, 1990.

Gjevori 1979 - Gjevori M. Frazeologjizma të gjuhës shqipe. Tiranë: Shtëpia botuese "8 Nëntori”, 1979.

Glück 1892 - Glück L. Narodni lijekovi iz bilinstva u Bosni. Etnografska studija. Glasnik ZemaljskogMuzeja u Bosni i Hercegovine. 1892. S. 134-167.

Golant 2020 - Field materials by N.G. Golant. Vlachs of Eastern Serbia. 2020.

GRE s.a. - Great Russian Encyclopedia. Electronic version. https://bigenc.ru/ agriculture/ text/2952691 (access date: 08.02.2021).

Kostallari 1980 - Kostallari A. (kryered.) Fjalor i gjuhës së sotme shqipe. Tiranë: Akademia e Shkencave e RPS të Shqipërisë; Instituti i Gjuhësisë dhe i Letërsisë, 1980.

Lafe 2008 - Lafe E. (red.) Fjalor enciklopedik shqiptar. Vëll. I. Tiranë: Akademia e shkencave eShqipërisë, 2008.

LOP 1980 - Life of plants: In 6 v. Main ed. A.A. Fedorov. V. 5. P. 1: Flowering plants. In A.L. Takhtadjan (ed.). Moscow: Prosveschenie, 1980.

Meyer 2007 - Meyer G. Fjalor etimologjik i gjuhës Shqipe - 1891. Përkth. A. Omari. Tiranë: BotimeÇabej, 2007.

Mitrushi 1955 - Mitrushi I. Drurët e shkurret e Shqipërisë. Tiranë: Instituti i shkencave, 1955.

Neer van der 2007 - Neer van der J. On the most amazing plants. Saint Petersburg: Kristall; Moscow: Onix, 2007.

Newmark 2000 - Newmark L. The Albanian-English Dictionary. Oxford: Oxford University Press, 2000.

Nopcsa 1913a - Nopcsa F. Albanien. Kultura shpirtërore: Shqipëria. Materiale të përkthyera,dorëshkrime, shkruar më 1913. Arkivi i Institutit të Historisë. Tiranë.

Nopcsa 1913 b - Nopcsa F. Albanien. Pikëpamje fetare. Vepër dorëshkrim, e përkthyer, shkruar më 1913. Arkivi i Institutit të Historisë. Tiranë.

Produktet tona n.d. - Produktet tona. Organic shop. Produkte të natyrës. https://organicshop. al/ produktet-tona (access date: 21.12.2020).

Reçel fiku 2020 - Reçel fiku. Nerti. Arti Gatimit. 20.06.2020. https://www.artigatimit. com/2013/08/recel-fiku

Sulaj 2013 - Sulaj E. (red.) Bimët Mjekësore - Instituti i shkencave - 1980. Tiranë: Shtëpia botuese:Akademia e Shkencave dhe e Arteve e Kosovës, 2013.

Šulek 1879 - Šulek B. Jugoslavenski imenik bilja. Zagreb: Jugoslavenska akademija znanosti i umjetnosti, 1879.

Tolstaya 2019 - Tolstaya S.M. (ed.-in-chief). Slavic mythology. Encyclopedic Dictionary. Moscow: Mezhdunarodnye otnoshenia, 2019.

Tolstoy 1957 - Tolstoy I.I. (comp.) Serbian-Croatian-Russian Dictionary. Moscow: St. publ. house of foreign and national dictionaries, 1957.

Tolstoy 1995-2012 - Tolstoy N.I. (ed.). Slavic antiquities. Ethnolinguistic dictionary: In 5 v. Moscow: Mezhdunarodnye otnoshenia, 1995-2012.

Topalli 2017 - Topalli K. Fjalor etimologjik i gjuhës shqipe. Tiranë: Qendra e studimeve albanologjike;Instituti i Gjuhësisë dhe i Letërsisë, 2017. 
Usikova, Verizhnikova 2003 - Macedonian-Russian Dictionary. In-R.P. Usikova, E.V. Verizhnikova (eds.). Moscow: Astrel; AST, 2003.

VegaGo.ru s.a. - Vegan and vegetarian - what's the difference? VegaGo.ru. https://vegago. $\mathrm{ru} / \mathrm{read} / \mathrm{vegan}-\mathrm{i}-\mathrm{vegetarianecz-v-chem-raznicza.html} \mathrm{(access} \mathrm{date:} 22.12 .2020$ ).

Ymeri 2005 -Ymeri E. (ed.) Fjalor rusisht-shqip. Tiranë: EDFA, 2005.

\section{References}

Adamou, E., and Y. Matras, eds. 2021. The Routledge Handbook of Language Contact. London: Routledge Taylor \& Francis Group.

Arutyunov, S.A. 1981. Vvedeniye [Introduction]. In Etnografiia pitaniia narodov stran zarubezhnoi Azii [Ethnography of Nutrition of the Peoples of Foreign Countries of Asia], edited by S.A Arutyunov, 3-11. Moscow: Nauka.

Bart, R. 2018. Sistema mody. Stat'i po semiotike kul'tury [Fashion System: Articles on the Semiotics of Culture]. Moscow: Akademicheskii proekt.

Gjergji, A. 1988. Veshjet shqiptare në shekuj. Origjina. Tipologjia. Zhvillimi [Albanian Clothes for Centuries: Origin, Typology, Development]. Tiranë: Akademia e Shkencave e RPS të Shqipërisë;Instituti i Kulturës Popullore.

Gjergji, A. 2002. Mënyra e jetesës në shekujt XIII-XX. Përmbledje studimesh [The Way of Life in the $18^{\text {th }}-20^{\text {th }}$ Centuries: Summary of Studies]. Tiranë: KOTTI.

Grosheva, A.V. 2011. Smokovnitsa (lat. Fīcus) [Fig Tree (lat. Fīcus)]. In Indoevropeiskoe yazykoznanie iklassicheskaia filologiia - XV. Materialy chtenii, posviashchennykh pamiati professora Iosifa Moiseevicha Tronskogo. 20-22 iiunia 2011 g. [Indo-European Linguistics and Classical Philology - XV. Materials of Readings Dedicated to the Memory of Professor Iosif Moiseevich Tronsky. June 20-22, 2011], edited by N.N. Kazanskiy, 112-127. St. Petersburg: Nauka.

Joseph, B., A. Novik, A.N. Sobolev, and A. Spiro. 2019. Greek and Albanian in Palasa and Environs: A Report from the Field. MGDLT. Modern Greek Dialects and Linguistic Theory: Proceedings of the International Conference Series of Modern Greek Dialects and Linguistic Theory 8 (1): 69-78. https://resmicte.library.upatras.gr/mgdlt/article/view/3007/3339

Kharitonova, V.I. 2006. Feniks iz pepla? Sibirskii shamanizm na rubezhe tysiacheletii [Phoenix from the Ashes? Siberian Shamanism at the Turn of the Millennium]. Moscow: IEA RAS.

Krstić, K. 1988. Doseljenje Arbanasa u Zadar [Arbanasi Moved to Zadar]. Lib. 3. Zadar: Mjesna zajednica Arbanasi.

Novik, A. 2002. Katolički praznici, obredi i narodno hrišćanstvo u Dukađinu. Građa sa ekspedicije usevernoalbanske Alpe [Catholic Holidays, Rituals and Folk Christianity in Dukagjin: Material from the Expedition to the Northern Albanian Alps]. In Kult svetih na Balkanu. II. Primljeno na 17. Sednici Naučnog veća Centra za naučna istraživanja SANU i Univerziteta u Kragujevcu. Biblioteka LICEUM. Knjiga 7 [The Cult of Saints in the Balkans. II. Received at the XVII Session of the Scientific Council of the Centre for Scientific Research SASA and University of Kragujevac], edited by N. Tasić, 145-165. Kragujevac: Centar za naučna istraživanja Srpske akademije nauka i umetnosti i Univerziteta u Kragujevcu.

Novik, A.A. 2014. Buzmi, novogodniaia yelka i nachalo goda u albantsev Balkan i diaspory [Buzmi, New Year Tree and the Beginning of the Year Among the Albanians of the Balkans and the Diaspora]. In Nachalo. E archế. Fillimi. Inceputul... Rozhdestvo i Novyy god na Balkanakh [Beginning. H $\alpha \rho \chi \eta ́$. Fillimi. Începutul... Christmas and New Year in the Balkans], edited by I.A. Sedakova, 72-86. Moscow: Institut slavianovedeniia RAN.

Novik, A.A. 2017. Arbneshi Zadara: opyt polevoi raboty v Khorvatii v 2016 g. [Arbneshi of Zadar: The Experience of Field Work in Croatia in 2016]. In Radlovskii sbornik. Nauchnye issledovaniia $i$ muzeynye proekty MAE RAN v $2016 \mathrm{~g}$. [Radlov Collection: Scientific Research and Museum Projects of the MAE RAS in 2016], edited by Y.K. Chistov, 133-143. St Petersburg: MAE RAN. Novik, A.A., and Y.A. Rezvan. 2019. Islam na Balkanakh. Ch. I, Obriady perekhoda $i$ semeinaia obriadnost': rozhdenie, obrezanie [Islam in the Balkans. Pt I, Rites of Passage and Family Rituals:

Birth, Circumcision]. St. Petersburg: Izdatel'stvo Sankt-Peterburgskogo universiteta.

Plotnikova, A.A. 2004. Etnolingvisticheskaia geografiia Yuzhnoi Slavii [Ethnolinguistic Geography of South Slavia]. Moscow: Indrik. 
Sidneva, S.A. 2008. Rastitel'nyi kod v novogrecheskom fol'klore [Plant Code in Modern Greek Folklore]. PhD diss., Moscow State University.

Sikimić, B., and T. Ašić, eds. 2008. The Romance Balkans. Belgrade: Institute for Balkan Studies ofSASA.

Sobolev, A.N., and A.A. Novik, eds. 2013. Golo Bordo (Gollobordë), Albaniia. Iz materialov balkanskoi ekspeditsii RAN i SPbGU 2008-2010 gg. [From the Materials of the Balkan Expedition of RASand SPbSU in 2008-2010]. St. Petersburg: Nauka; München: Verlag Otto Sagner.

Stipqeviç, A. 2012. Kultura tradicionale e Arbëneshëve të Zarës [The Traditional Culture of the Arbënesh of Zadar]. Prishtinë: Instituti Albanologjik i Prishtinës.

Tirta, M. 2004. Mitologjia ndër shqiptarë [Mythology among Albanians]. Tiranë: Akademia e Shkencave e Shqipërisë, Instituti i Kulturës Popullore.

Tirta, M. 2006. Etnologjia e shqiptarëve [Ethnology of Albanians]. Tiranë: GEER.

Tirta, M. 2007. Panteoni e simbolika: doke e kode në etnokulturën shqiptare [Pantheon and Symbols: Rituals and Codes in Albanian Ethnoculture]. Tiranë: Nënë Tereza.

\section{Funding information}

The original research was supported by the following institutions and grants:

Russian Science Foundation, https://doi.org/10.13039/501100006769 [grant no. 19-18-00244] 